\title{
The humorous language of street dissent: A discourse analysis on the graffiti of the Gezi Park protests
}

\author{
Oya Morva \\ Istanbul University \\ oyamorva@istanbul.edu.tr
}

\begin{abstract}
Owing to its critical and creative potential, humour has often been used as one of the preferred means of resistance in social and political protests. In addition, the presence of humour is also increasing in the new social movements of recent history. The essential questions that this article aims to answer are how humour functions and what its purpose is amidst a time of numerous and notable social movements. During the 2013 Gezi Park protests in Turkey, the protesters made significant use of humour that specifically targeted the control of the authorities over public life, thus providing a good case with which to study humour in social movements. One form which the protesters used to disseminate humorous messages was graffiti. In this article, the graffiti from the Gezi Park protests is examined using a critical discourse analysis model. In order to achieve the intended aims, Van Dijk's (1995) understanding of ideological discourse analysis arguing that dominated groups may have ideologies that effectively organise the social representation needed for resistance and change, is taken as a point of departure. However, this work specifically relies on Fairclough's (1992) three dimensional discourse analysis that covers the object (the text), the process (discursive practice) and the socio-historical conditions (social practice). Research on the language of Gezi graffiti shows that the humorous language of the protesters identified and differentiated the actors of the movement, and it did not only help them to cope with the domination and oppression to which they were subjected, but also increased support for development in the desired direction.
\end{abstract}

Keywords: humour, social movements, graffiti, Gezi Park protests, discourse analysis.

\section{Introduction}

Humour, in various forms, has always been an element of the social protest tradition. It is still a very au courant form of protest, particularly considering social movements in recent history such as "pro-democracy movements in Eastern Europe, the global justice movement which emerged at the turn of the millennium and the current indignados movement both in its 
Western version and its non-Western one" (Romanos 2012: 4). The 2013 Gezi Park protests in Turkey, with their extensive use of humour in a variety of forms, can also be categorised under this list of recent social movements.

There are specific functional characteristics of humour that help explain its widespread usage in political protest traditions and in social movements. The literature on humour can be split into two broad categories according to its function in different circumstances, on different occasions: "first the individual level - why individuals use humour, and second, the societal level - the function of humour has within a social setting or society" (Lynch 2002: 423). Although both individualistic and societal levels of the functions of humour are related, this study adopted a point of view derived solely from the second category, humour at the societal level, in order to answer the research question of how humour functions in social movements. Before moving to the analysis, it is worth examining the Gezi Park movement and its socio-political background.

\section{What happened at Gezi? Who was involved in what relations?}

The Gezi Park movement, which occurred between May and June 2013, was one of the most notable political events in the recent history of Turkey, and ended with eight fatalities and thousands wounded. According to statistics from the Home Secretary, there were 5532 protests, which occurred in 80 different cities across Turkey. There was only one city in which there were no protests (The National Human Rights Institution of Turkey 2014) ${ }^{1}$. Despite starting as a protest of the environmentally conscious middle classes, it became a nation-wide strike that embraced a wide range of people from different demographics. Initially, it was an environmental protest targeting the government's urban development plan of Istanbul's Taksim Gezi Park, a government-approved plan permitting the building of a shopping mall on the Park, but it became clear that there was much more motivation behind the protests. Therefore, in order to understand and explain the dynamics of the Gezi Park movement, one should take into consideration the recent political climate of the country.

Adalet ve Kalkınma Partisi (hereafter AKP), which translates to English as "Justice and Development Party", has been in power as the ruling party of Turkey since 2002. AKP, which can be described as a conservatist democratic, right wing party, embraced reformist policies during the first period (2002-2007) of its governance: the party adopted a liberal market economy and attached importance to the cooperation with the West. This period is generally accepted as the golden age of Turkish-EU relations in terms of its foreign policy program. This reformist identity of the party, according to Sahin (2013), helped AKP to obtain the support of liberal intellectuals all over the country. AKP's economic success, on the one hand, and democratisation moves that aimed at becoming a member of EU, on the other, gave rise to its political success (Sahin 2013:166). Therefore, despite the significant defiance of "Kemalist" elites and secularists, AKP widened its lead over the opposition parties in the election of 2007 and started its second term of governance. However, after the elections of 2011 (or, more specifically, starting from the latter period of its second term), AKP has changed from a liberal conservatist-reformist party to a nationalist-conservatist statist party. In other words, during its third period of governance -in which Gezi protests occurred-AKP adopted more conservatist policies, which aimed to strengthen its own power and impose its conservative ideology (Sahin 2013:166).

One way of explaining the transformation of the Party's policies can be found by emphasising AKP's neo-Ottomanism. Czajka \& Wastnidge (2015) argue that AKP has neoOttomanist tendencies not only in its foreign policy but also in its domestic policy. This neoOttoman perspective of the Party can be described as taking the liberal, multicultural ${ }^{2}$ and 
Islamist view of the Ottoman Empire. Referring to the liberal and multicultural views, despite promising to continue such legacies at the beginning of its first and second term of governance, AKP reneged on this promise. As Czajka \& Wastnidge state (2015: 12), "though the Party began its term in government with the promise of democratisation and recognition of equal status of religious and ethnic minorities in Turkey, inequality persists between various groups in Turkey".

On the other hand, the Islamist perspective of its neo-Ottomanism was correctly defined as "an anti-dote to excesses of Kemalism, with its militant secularism, nationalism and Westernisation" (Czajka \& Wastnidge 2015: 3). Taking this statement as a departure point, it can be argued that the neo-Ottomanism of the party has given rise to polarisation -which has been in existence since the foundation of the modern Republic of Turkey- between the Islamists and secularists of the country.

The Gezi Park protests have occurred within this political context and, as such, it is also possible to analyse the protests as a consequence of this social polarisation. However, this point of view is not adequate in explaining the process, since there were also other motivations such as "environmental concerns and critiques of capitalism that intermingled together" (Gole 2013). Furthermore, according to her,

[P]eople tend to nurture a fuzzy understanding of abstract notions such as capitalism, global powers, the finance world and neo-liberalism. In Turkey, however, capitalism has a name: the mall or AVM (Alışveriş Merkezi in Turkish)... Building an AVM at the very center of Gezi Park is, in the eyes of the residents of İstanbul, nothing but an act of plundering the public sphere or a place open to citizens being committed by private capitalists.

(Gole 2013)

In this case, the Gezi movement has also been read as a reaction of the urban area's new middle classes to the neo-liberal economic practices of the existing government. As Keyder (2013) indicates, neo-liberalism, on the one hand, exalted market rationality and, on the other, it reinforced the state's power through governmental privatisation of common areas and public lands. Therefore, during the Gezi movement, "protesters protect a public place against the commodification of the state and against the tendency to transform urban life into a source of lucre" (Gole 2013). This struggle for a public place, for the Park, also symbolically refers to the struggle for an efficient and democratic public sphere which "was shrinking in the pre-Gezi era" (Gole 2013) due to the government's interventionist discourses on people's lifestyles, and their restrictions on some democratic freedoms and rights (such as freedom of assembly, of expression, of the press, media, pluralism, etc.). Indeed, according to statistics, the majority of protesters $(58.1 \%)$ were involved in the movement for reasons of freedom (KONDA Research and Consultancy 2014) ${ }^{3}$.

Much of the Turkish mainstream media downplayed or ignored the protests (this point arguably also exemplifies the above-mentioned shrinking public sphere); therefore social media played a key role during the process. The protesters made significant use of humour online; they also used graffiti (mostly on the walls of various metropolises) to disseminate humorous messages. There was, as the BBC called it, "an explosion of expression in the form of satire, irony and outright mockery of the popular leader (President Erdoğan) on Istanbul's streets and social media" (Sabral \& Erdim, 2013). Similarly, some investigators (Emre et al. 2013: 6) stated that "by adopting a witty, wise, funny and fearless language, the Gezi Park protesters created a new resistance language that refuses violence, carries peaceful, naive and optimistic messages [and] praises apoliticism and inorganisation".

Before moving to the analysis of this humorous language, it should also be noted that, although the culture of humour has developed and changed in and across many forms (magazines, TV programmes, talk shows, movies, etc.) throughout the ages in Turkey, the 
attitude of politicians or governments has always been either to tolerate or restrict such humour, because of its critical power. Neither AKP nor President Erdoğan has been seen as especially tolerant of it during their power. Therefore, the humour of the Gezi movement also targets this intolerant attitude and, when discussing the humorous language of the Gezi Movement, it is necessary to take into consideration the stated political background of the country.

\section{Data and methodology}

One form which the protesters used widely to disseminate humorous messages during the Gezi Park protests was graffiti; such a form can also be referred to as street slogans following Kitis' (2011) use of the phrase to refer to graffiti which mostly consist of apophthegmatic statements and phrases. Graffiti are a very powerful mode of expression for groups that feel disenfranchised by wider society (Hanauer 2004). It is a communicative act which has a particular set of social interactional roles such as: 1) allowing the entry into public discourse of messages regarded as marginal by other media; 2) providing the individual with the opportunity to express controversial content publicly; and 3) offering marginal groups the possibility of expressing themselves publicly. The graffiti of the Gezi movement created by the protesters fulfilled all these roles and humour was their trademark.

This study draws on critical discourse analysis to explain these humorous graffiti messages and it specifically relies on Fairclough's (1992) three dimensional version of discourse analysis. Van Dijk's (2015) understanding of ideological discourse is also taken as a point of departure, according to which ideologies are not necessarily negative or false. According to him, dominant groups may have ideologies that they use to legitimate their power or to manufacture consent or consensus; dominated groups may also have ideologies that effectively organise the social representation needed for resistance and change. In this case, Gezi Park graffiti can be considered as a genre that reflects the dominated group's ideological stances. Starting with this consideration, Fairclough's (1992) three dimensional discourse analysis model covers the object of analysis (the text), the processes through which the object is produced and received (discursive practice), and the socio-historical conditions which conduct these processes (social practice), and has been chosen to analyse the discourse of the graffiti.

Focusing on the Gezi protests, the present analysis does not only show how humour functions but also elaborates on its purposes during the current era of social movements. The following questions are addressed:

- How are humorous discourses activated textually by the linguistic characteristics of the graffiti?

- How did the social and discursive practices combine during the Gezi protests?

- What was the role of humorous discourse during the Gezi movement?

Within this study, 43 examples of graffiti produced during the Gezi Park protest (mostly on the walls of various metropolises) were analysed. The research covers the data mainly collected from various online platforms such as web pages and social media networks. Most of the material was obtained from three web pages. For a complete list of the analysed graffiti see Appendix 1. 


\section{Textual analysis of the graffiti}

The first analytical focus of Fairclough's (1992) three dimensional discourse analysis model is the text. As Jorgensen \& Phillips (2002: 83) state, "by detailed analysis of the linguistic characteristic of a text, it is possible to cast light on how discourses are activated textually and arrive at, and provide backing for, a particular interpretation". Fairclough's (1995: 56) analysis of text involves linguistic analysis in terms of vocabulary, grammar, semantics, the sound system and cohesion-organisation above the sentence level. He proposes a number of tools for the analysis of the text: interactional control (referring to the relationship between speakers), ethos (referring to how identities are constructed through language), metaphors, wording and grammar (Jorgensen \& Phillips 2002: 83).

\subsection{Interactional control and ethos}

In the cause of anatomising the social relations of speakers and the construction of identities in graffiti messages, one should investigate how the graffiti messages construct the representations of the reader and the writer themselves. In the graffiti, one can define three different constructed readers of the messages:

1. The power - in this case referring to the existing government, the prime minister and mostly the police force (as can be seen in the graffiti of "Dear police, you're literally bringing tears to our eyes", "We take that gas in a single hit bro!" "You banned alcohol, the people sobered up!","You're messing with the generation that beats cops in GTA!", "We are a generation that ran after insect fumigation trucks. What is gas to us?", "Dude, don't be scared. It's us. The people!", "You shouldn't have banned that last beer!", "Police! Help! Oh, nevermind, I guess you're busy", "We are already emotional kids, no need for tear gas!", "You can't scare a people who checks for gas leakage with a lighter by using tear gas", "Antarctica is resisting!", "Are you aware of the danger? --No Candy Crush requests for days!", "Now I'm a gas addict, bud!" , "Police, don't be a bad ass!", "State, wake up and spray pepper to your rebels!", "No revolution, nor religious law, only respect!", "Mr. Policeman, you are also insolent as much as you are ugly!", "Welcome to Fight Club Tayyip!", "We haven't taken a shower for 3 days, so send us RCV's!", "We are constantly kissing Tayyip!", "Do you want 3 kids like me?”, "Pepper spray ole!”, “Another serving of gas, please!”).

2. The well-wishers who are not actively resisting, but support the protesters (as can be seen in the graffiti of "Don't worry mum, I am not at the front line, we walk together!", "Welcome to the 1st Traditional Istanbul Gas Festival", "I'm neither a leftist nor a rightist, but a chapullist (or chapuller)"," "The New Democrat Youth of Turkey: Chocolate is the only solution", "We are all Pokemons", "We are soldiers of Freddie Mercury!", "We are soldiers of Mustafa Keser"6", "I asked God what to do. He replied \#direngezi" ", "The people are Clark Kent during the day, and Superman during the nighttime", "I couldn't think of any slogans").

3. The protesters themselves (as can be seen in the graffiti of "Rebel so hard, Tayyip wanna gas me!", "Dude, this gas is awesome!", "Tear gas enhances skin's beauty", "At first everything was a gas cloud. Then life began!", "I asked God what to do. He replied \#direngezi", "It's hard to die in June", "I had my breakfast, now I can rebel", "In Taksim we trust!") 
Although the same humorous tone of language is used to represent all these constructed readers, there are differences in constructing the representations. The power (government, PM, police etc.) was described with negative words in an adversarial, inhospitable and a threatening manner (as can be seen in the graffiti of "Police don't be a bad ass!", "Mr. Policeman, you are also insolent as much as you are ugly!", "Welcome to Fight Club Tayyip!" etc.). On the contrary, the discourse of the graffiti's demand for solidarity amongst the members of protesters and their well-wishers was displayed in an all-embracing manner ("Welcome to the $1^{\text {st }}$ Traditional Istanbul Gas Festival", "I'm neither a leftist nor a rightist but a chapullist", etc.). The choice of words for mocking the power in graffiti was informal and new-fashioned contributing to a subjective and unconventional identity that can also build sovereignty (as can be seen in the graffiti of "Dude, don't be scared. It's us. The people!", "We take that gas in a single hit bro!", "Now I'm a gas addict, bud!" etc.). Besides, in some of the graffiti, the chosen words even referred to a specific cartoon character or a computer game that would only be understood by the protester's own generation ("We are all Pokemons", "You're messing with the generation that beats cops in GTA", "Are you aware of the danger? --No Candy Crush requests for days"). Hereby, they were able to exclude the others and separate themselves from the power.

In other words, the graffiti of Gezi can be classified according to its targeted readers. Kutz-Flamenbaum's (2014: 294) categorises humour as either external or internal depending on its intended target. The former refers to the kind of humour directed outside the group in the form of tactics and frames and the latter refers to the role of humour in leadership, collective identity and emotional labour. In the case of the Gezi Movement, the textual quality of the graffiti reflects the characteristics of both categories: the graffiti is external when the protesters' humour targets the power. However, on the other hand, it is internal when they target themselves or the well-wishers.

\subsection{Wording and grammar}

When one looks more closely at the grammatical elements and analyses the transitivity showing how events and processes are connected with subjects and objects, it is found that all sentences in the graffiti are mostly in the active form ("Rebel so hard!", "I am chapulling!", etc.): the subjects are represented as responsible agents. The graffiti's sentence structure emphasises the agent of responsibility by using the active form when referring to the protesters ("I had my breakfast, now I can rebel!", "We walk together!" etc.) or incriminates the agent of responsibility by using the active form when referring to the power ("You banned alcohol, the people sobered up!", "You shouldn't have banned that last beer!"). Nominalisation, whereby a noun stands for the process, which Jorgensen \& Phillips (2002: 83) define as another linguistic feature that reduces agency and emphasises the effect, has not been used in the graffiti. On the contrary, for example, çapulcu (roughly translated as "looter", see endnote 4), the noun coined by the prime minister to describe the protesters in an insulting manner, is adopted as a neologism and used as a verb in the active form by the protesters ("I am chapulling everyday", "I am chapulling in Istanbul, my eyes wide shut", etc.) .

The modality element which focuses on the speaker's degree of affinity with the statement can be described as "a strong claim to truth, which implicates the identity of one who knows and the complementary identity of one who does not know" (Fairclough 2003: 13). Different discourses use different forms of modality, for instance, the mass media often presents "interpretations as if they were facts partly by choosing objective rather than subjective modalities. For example, by saying it's dangerous instead of we think it is dangerous" (Jorgensen \& Phillips 2002: 84). In our case, most of the graffiti uses subjective 
modalities, such as "I am chapulling in Istanbul, with my eyes wide shut", "We have been dating RCVs for 8 days", "Now I'm a gas addict, bud!", via which the speaker commits herself/himself completely to the statement. Permission is another way of constructing social relations with a modality element. In graffiti, the writer puts only himself/herself in a position whereby they give or do not give the receiver permission to do something: "You can't scare a people who checks for a gas leak with a lighter by using tear gas!". Moreover, there are samples that the protesters are in charge of doing something by themselves ("I had my breakfast, now I can rebel"). In this way, they have equated themselves with the power itself.

Intertextuality is an element of textual analysis of discourse that refers to relationships held internally between texts. Fairclough (1992: 104-105) defines two types of intertextuality: manifest intertextuality and constitutive intertextuality. Regarding manifest intertextuality, he states that "other texts are explicitly presented in the text under analysis; they are manifestly marked or cued by features on the surface of the text, such as quotation marks" (Fairclough 1992: 104). On the other hand, constitutive intertextuality refers to "the configuration of discourse conventions that implicitly contribute to the production of text" (idem: 105) where the confluence of discourse conventions includes: "genres, voices and types of discourse" that, viewed together, form a text (Hodges 2011: 9). In the case of Gezi park, both types of intertextuality can be found, and these can be seen as means through which people's attention and interest in the graffiti texts can be aroused. "I am chapulling in Istanbul, with my eyes wide shut" (referring to one of the very famous line of Turkish poetry Istanbul'u Dinliyorum which means "I am Listening to Istanbul" by Orhan Veli, one of the most famous Turkish poets; it can be described as a well-known city poem about Istanbul), "At first everything was a gas cloud. Then life began!"'(referring to the very first sentence of the biblical book of Creation), "It's hard to die in June" (referring to another very famous line of Turkish poetry Haziranda Ölmek Zor by Hasan Hüseyin Korkmazgil. This poem has been written after the death of another famous poet, Nazım Hikmet, who was known as a romantic revolutionary), etc. By using intertextuality, protesters also identify themselves with some symbols. In this case, this symbol in the first graffiti is Istanbul (the city where the protests have begun); in the second one it's a new life (the sentence from the Bible refers to a start; similarly the protests refers to a new beginning) and in the last graffiti it is Nazım Hikmet himself who lived and wrote as a revolutionary and also died in June.

It is also noted that, by using intertextuality, protesters can build a conversational dialogue between the two texts and displace the meaning from one text to another. Intertextuality is defined as being deconstructive rather than constructive and "this deconstructive intention can, in some cases, certainly have a critical and even a political function" (Broich 1997: 253). These characteristics of intertextuality can be seen in the Gezi graffiti, too. For example, in the case of examples of graffiti such as: "We are the soldiers of Freddy Mercury" or "We are the soldiers of Mustafa Keser", protesters reject attempts to identify themselves only as secular nationalist groups who are against the Islamist AKP governance. Thus, through the humorous usage of intertextuality in graffiti, protesters refuse to represent a certain ideological stance and instead choose to emphasise their diverse profiles from environmentalists to football fans, from left-wing Islamists to Kurds, to Alevis ${ }^{8}$ or to Marxists.

\section{Humorous language as social and discursive practice: What was the role of language during the Gezi movement?}

The textual analysis of the graffiti reveals that the protesters mostly use a humorous language in order to resist and protest. Therefore, it is appropriate to delineate the concept and theories 
of humour, since its sociocultural role and functions determine the social and discursive practice of our communicative events.

There is not just one definition for humour, on the grounds that it is an umbrella term that covers such concepts as satire, parody, irony, wit, joking, teasing, etc., "each with its own tangible (perlocutionary) effects and its own types of laughter (or even other reactions)" (Vandaele 2002: 155). In addition, humour is a universal phenomenon; it exists in every culture in diverse forms, which also makes the definition of the term and its functions difficult to outline. As mentioned in section 1, humour can basically be split into two broad categories: first, the individual level and, second, the societal level. Focusing on the second category, there are two dualistic functions of humour at the societal level: identification or differentiation and control or resistance. The first one, identification or differentiation, can be described as that which "excludes individuals or groups who do not have the knowledge of the in-group's reference or structure" (Lynch 2002: 434). At the same time, according to Lynch (2002: 434) "[it] can extend and express pre-existing boundaries of divergence in social groups such as gender, nationality, race, religion or occupational position". In the case of the Gezi graffiti, this dualistic function is attested: there is an explicit emphasis on the differentiation (we, the protesters, against the other(s), the power/authorities), which reflects a strong identification for the members of both sides ("State, wake up and spray pepper to your rebels!", "Dude, don't be scared. It's us. The People!", etc.). As mentioned in section 4, choosing a humorous language derived from new generation social media platforms, cartoons or computer games ("We are Pokemons", "Are you aware of the danger? No Candy Crush requests for days!", "You're messing with the generation that beats cops in GTA!") makes it possible to exclude the other, namely the power and all of its conventional and authoritarian discourses and practices. It should also be noted that, apart from its humorous contents, graffiti writing itself is also always "about establishing particular types of identity" (Pennycook 2010: 60) which differs from the power itself. On the other hand, in opposition to Lynch's (2002) point regarding extending the pre-existing order of the social system, in our case, this differentiation and identification process aims to disband all kinds of hierarchical order within and outside of the group. Since the present communicative event pertains to social conflict and resistance, it can be seen as a struggle for an efficient and democratic public sphere which was shrinking in the pre-movement era, and therefore as a demand to change the pre-existing order.

The second function of humour on a societal level is control or resistance. We can describe this as the power-related function of humour. According to this approach, humour can act as both control and resistance (Lynch 2002: 434). Conflict theories of humour can be categorised under this title. As Kuipers (2008: 372) notes, conflict theories see humour as an expression of conflict, struggle, or antagonism: "humour is interpreted not as venting off -and hence avoidance or reduction - but as an expression or correlate of social conflict: humour as a weapon, a form of attack, a means of defence". Hence, humour is associated with resistance and power relations within society. Again, in the Gezi case, the graffiti entail messages that can be read as a form of attack on and challenge to power (as can be seen in the graffiti of "You shouldn't have banned that last beer", "You can't scare a people who checks for gas leakage with a lighter by using tear gas", "Rebel so hard, Tayyip wanna gas me!", "Welcome to Fight Club", “We haven't taken a shower for 3 days, so send us RCV's", etc.).

Linking humour with the power relations of society is an old tradition in humour studies that has its roots mostly in Bakhtin's famous book Rebelais and His World (1984). Bakhtin (1984: 92) argues that "laughter presents an element of victory not only over supernatural awe, over the sacred, over death; it also means the defeat of power, of earthly kings, of the earthly upper classes, of all that oppresses and restricts". Accordingly, humour, as a site of resistance, appears in Bakhtin's description of the carnival culture of the Medieval Ages. He 
describes carnival as "the people's second life, organised on the basis of laughter. It is a festive life. Festivity is a peculiar quality of all comic rituals and spectacles of the Middle Ages" (Bakhtin 1984: 8). The carnival, according to him, "opposed to the official feast and celebrated temporary liberation from the prevailing truth and from the established order, it marked the suspension of all hierarchical rank, privileges, norms, and prohibition" (Bakhtin 1984: 7). Gurevich (1997: 57) argues that "at the heart of carnival was the idea of overturning reality, the tradition of turning the established social and religious order upside down". That is to say, carnival was hostile to all that was immortalised and completed, carnival was about renewal (Bakhtin 1984). Carnavalesque events are reactions to the institutions and structures of any kind of authority through inversion, mockery and other forms of humour. "Carnival and carnivalesque creates an alternative for a new social sphere, a chance for a new perspective and new orders of things" (Robinson 2011).

As Yegenoglu (2013) states, during the Gezi Park protests "a robust sense of humour accompanied the placards, slogans and songs, turning the protests into a carnivalesque event" in a Bakhtinian sense. During the protests,

[t]he protesters have created a utopian atmosphere of egalitarian community, autonomy and liberation through which they have challenged the existing forms of hierarchy. In such a community, where participants are positioned as equals, the prevalent social positions, norms, habits, ideas and ritualised practices are challenged and different ones installed, as the community as a whole acts against structures of hierarchy.

(Yegenoglu 2013)

Departing from this view, one can define one function of humour as "turning all kinds of dominations and oppressions upside down" (Sorensen 2008: 175). In the case of the Gezi movement, as mentioned in section 1, the movement itself and its graffiti can be read as a reaction of the new middle classes to the government's interventionist discourses that targeted people's lifestyles, and to the government's restrictions on democratic freedoms and rights. In the graffiti, the protesters reject this oppression by the authorities by mocking it directly: they mostly targeted the Prime Minister himself and the police force. ${ }^{9}$ Thus, by rejecting the oppressors' power over them, the protesters tried to reverse the power roles ("Police! Help! Oh, nevermind, I guess you're busy!", "Mr Policeman, you are also insolent as much as you are ugly", "Welcome to Fight Club Tayyip", etc.).

Sorensen (2008: 175) suggests two further ways in which humour functions as a form of nonviolent resistance. The first is "facilitating outreach and mobilisation" with people outside the movement. As Kuipers (2008: 366) states,

humour not only is a sign of closeness among friends, it is also an effective way of forging social bonds, even in situations not very conducive to closeness: it breaks the ice between strangers, unites people in different hierarchical positions, and creates a sense of shared conspiracy in the context of illicit activities like gossiping or joking about superiors.

Thus, the Gezi graffiti does not only target the oppressors themselves, but also the movement's well-wishers ("Don't worry mum, I am not at the front, we walk together!") and welcomes everyone who wishes to resist ("Welcome to the $1^{\text {st }}$ Traditional Istanbul Gas Festival", etc.). Hardt's (2014) evaluation regarding the Gezi movement as "expanding the social composition" helps one to understand how the graffiti of Gezi facilitates this outreach and mobilisation by targeting well-wishers from diverse groups. One of the most important and inspiring aspects of the Gezi encampment was, as Hardt (2014) explains, 
the way it opened the possibility for new political subjectivities and new articulations across the social spectrum. Rigid social divisions that previously seemed unbreachable suddenly seemed to dissolve among those together in the square.

He also adds that Gezi opened some potential connections amongst groups which are difficult to classify under the same ideological category such as feminist and LGBT activists, anticapitalistic Muslims and supporters of Kurdish movements, and that such connections are one of the most important of Gezi's effects. The humour used in the Gezi graffiti, targeting not only the people within the group but also the potential supporters and well-wishers from various social groups in a unifying manner increased the support for the development of the movement in a desired direction. Protesters, although coming from different ideological backgrounds, liberate all kinds of categorisations by mocking all ideologies as complete thoughts: "The New Democrat Youth of Turkey: Chocolate is the only solution!", "I couldn't think of any slogans", "We are the soldier of Freddy Mercury", "I'm neither a leftist nor a rightist, but a chapullist", etc. Having a common target -the ideological stance of the government- ("We are constantly kissing Tayyip", "Pepper sauce democracy!") and also a common demand ("No revolution, nor religious law, only respect") united them together: "Don't worry mum, I'm not at the front, we walk together", "Dude, don't be scared. It's us. The People."

The other function which Sorensen (2008: 175) discusses is that of "facilitating a culture of resistance" within the group, which builds solidarity and strengthens the individual's ability to participate in the resistance. Gezi graffiti produced its own unique language to facilitate a culture of resistance within the movement. As Kitis (2011: 54) explains, "language is the main fabric of society; it is a commodity shared by all members of a speech community, uniting them but also distinguishing them according to their level of competent use". The protesters' language derives from the young generation's cultural background, which includes references to the social media (as can be seen in the graffiti "Are you aware of the danger? No Candy Crash requests for days!", "I asked God what to do. He replied \#direngezi", etc.), the youth culture of the country ("We are constantly kissing Tayyip") and popular culture icons ("We are the soldiers of Freddie Mercury", "We are soldiers of Mustafa Keser"). According to Emre et al. (2013: 7), "this individual, funny and humorous language acted as a unifying factor for a social movement based on anti-violence as well". Considering the idea that "communication between members of society and between members and authorities is effected through language" (Kitis 2011: 55), the protesters humorously criticise the hegemonic power in their own way. Thus, they have created a unique way of communicating among themselves and also a culture of resistance which demands a new form of relationship with the authority.

\section{Conclusion}

Humour, in various forms, has always been related with social protest tradition and it was the hallmark of the 2013 Gezi protests in Turkey, too. There was extensive use of humour during the movement, and one form which the protestors used widely was graffiti. The textual characteristics of the humorous graffiti, which refers to one of the three dimensions of Fairclough's (1992) discourse analysis approach, explain how the discourse of the protestors was activated and delivered to the readers to create a particular interpretation. According to the analysis, the humour of the Gezi graffiti targeted three different groups of potential readers (the power, the well-wishers and the protesters themselves). Therefore, three different discursively constructed representations were activated, which aimed to create an intended interpretation of them. When concerned with the power, the representation and intended 
interpretation of it were described by using negative words in an unsympathetic and adversarial manner. Although the tone of their language was humorous and it did not constitute a direct threat, the protesters tried to reverse the power roles by representing themselves as the responsible agents by choosing subjective modalities. On the other hand, concerned with the protesters themselves and well-wishers, the representation involves demands for solidarity in a uniting manner. In some cases of graffiti, they also used intertextuality, which helped them to deconstruct the rigid political ideologies and to unify the protestors. In this manner, the textual characteristics of the graffiti, such as the choice of words to mock power, the grammatical elements, the forms of modality and the intertextuality have not only helped the protestors to give a voice to their resistance, but they have also constructed a collective, unifying identity.

Moreover, humour as a discursive and social practice (cf. the second and the third dimensions of Fairclough's 1992 approach) has functioned in relation to ingroup and outgroup relations among protesters on a societal level during the protests. The humorous language of the protesters identified and differentiated the actors of the Gezi movement. This dualistic function of humour is most evident in the Gezi case as the emphasis on differentiation reflects a strong identification: the protesters (we) against the power (the other). It also helped to turn authoritarian discourses upside down by its power-related function on a societal level: control and resistance. Considering that the Gezi movement was a reaction of the new middle classes to the government's interventionist discourses concerning their lifestyles, and its restrictions on democratic freedoms, humour helped them to reject this oppression. Therefore, the humour of the Gezi movement was directly related to resistance. Additionally, it facilitated a culture of resistance that enabled sovereignty to come into being. Thus, protesters support each other to overcome political and individual apathy, as well as become intermediators for people who are not actively part of the resistance movement, and hence the movement attracts more members.

Finally, Van Dijk's (1995) definition of ideology may be helpful to answer the question of what the role of humorous discourse was in the Gezi movement. According to him, dominated groups may also have ideologies that they use to effectively organise the social representation that is needed for resistance and change. Ideology might be constructed from such group-defining categories as identity/membership, activities, goals, norms and values, social position and resources, and thus it shows a polarising structure between us and them (Van Dijk 1995: 138). During the movement, humour functioned as an ideological tool in the group-defining process of the protesters. It was unique in belonging to that specific time period and to the distinct group of people who were united against state power. It helped to form a peculiar identity of the protesters which excludes the other, namely the power. Thus, the power/government lost its control over public discourse during the movement and this unique humorous discourse can be regarded as one reason for this. The humour, which contained informal and new-fashioned terms and belonged to a new generation of protesters, has created a subjective and unconventional identity and sovereignty that the power did not know how to handle.

\section{Notes}

${ }^{1}$ The National Human Rights Institution of Turkey (2014) Gezi Park1 olaylar1 raporu. Available online: http://www.tihk.gov.tr/www/files/5457741778378.pdf [accessed 12 August 2015].

${ }^{2}$ Although the liberal and multicultural structure of the Ottoman Empire is questionable considering its focus on the superiority of Muslims to others. 
${ }^{3}$ KONDA Research and Consultancy (2014). Gezi report. Available online: www.konda.com.tr/tr/raporlar/KONDA_GeziRaporu2014.pdf [Accessed 1 August 2015].

${ }^{4}$ The traditional meaning of the term has been rendered in English in a variety of ways, including the looters, the vandals or marauders. Despite its traditionally negative meanings, the protesters decided to reappropriate it in a positive manner after the Prime Minister used it in a speech during the Gezi movement to show his despise of the protesters. Thus, the term çapulcu and its neologisms have been widely used in graffiti and social media during the protests.

${ }^{5}$ The popular rock icon.

${ }^{6}$ A famous Turkish singer.

${ }^{7}$ Twitter tag of the movement.

8 The term Alevi refers to a type of heterodox Islam. Alevis constitute the largest religious minority in Turkey.

9 According to a KONDA report, $49.1 \%$ of the protesters decided to enroll in the movement after seeing the police violence, and a further $14.2 \%$ of the protesters enrolled after hearing the Prime Minister's statements on protesters and the movement.

\section{Appendix: The complete list of analysed graffiti}

1-Bu gaz bir harika dostum!

Dude, this gas is awesome!

2- Biber gazı cildi güzelleştirir.

Tear gas enhances skin's beauty. (Referring to a popular cosmetic advertisement)

3-Polis kardeş, gerçekten gözlerimizi yaşartıyorsunuz.

Dear Police, you're literally bringing tears to our eyes.

4- Biz o gazı tek kapakta alıyoruz moruk!

We take that gas in a single hit, bro!

5- Önce her şey bir gaz bulutuydu, sonra hayat başladı!

At first, everything was a gas cloud. Then life began!

6- Alkolü yasakladın, millet ayıldı!

You banned alcohol, the people sobered up! (Referring to a recent ban on alcohol implemented by the government)

7- GTA'da polis döven nesile sataştın!

You're messing with the generation that beats cops in GTA! (Referring to the Grand Theft Auto computer game)

8- Korkma lan, biziz, halk!

Dude, don't be scared. It's us. The people!

9- O son birayı yasaklamayacaktın!

You shouldn't have banned that last beer! (Referring to the ban on selling alcoholic drinks) 
10- Rabbime sordum, \#direngezi dedi.

I asked God what to do. He replied \#direngezi (Twitter tag of the movement)

11- İmdat Polis! Neyse, sen meşgulsün galiba.

Police! Help! Oh, nevermind, I guess you're busy.

12- Tüp kaçağını çakmak yakarak kontrol eden bir millet biber gazıyla korkutamazsın.

You can't scare a people who checks for a gas leak with a lighter by using tear gas.

13- Biz sinek ilacı aracının arkasından koşmuş nesilleriz. Gaz da neymiş?

We are a generation that ran after insect fumigation trucks. What is gas to us?

14- Biz duygusal çocuklarız, bibere gerek yok!

We are already emotional kids, no need for tear gas!

15- Antarktika direniyor!

Antarctica is resisting! (Referring to almost all the mainstream Turkish media which didn't broadcast any of the unrest during the first days of the protests and instead broadcast trivial stuff, with the most famous one being the penguin documentary that CNNTurk broadcast while CNN International was covering the protests in Istanbul)

16- İstanbul 1. Geleneksel Gaz Festivaline Hoşgeldiniz.

Welcome to the 1st Traditional Istanbul Gas Festival.

17- Ne sağcıyım ne solcu, çapulcuyum çapulcu.

I'm neither a leftist nor a rightist, but a chapullist (or chapuller) (Referring to "A few Capulcu", i.e., what the PM called the protesters in his speech)

18- Yeni Demokrat Gençlik: Tek Yol Çukulata

The New Democrat Youth of Turkey: Chocolate is the only solution

19- Gaz bağımlılık yaptı panpa.

Now I'm a gas addict, bud.

20- Polis, o.ç. olma!

Police, don't be a bad ass!"

21- Tehlikenin farkında mısınız? Günlerdir Candy Crush isteği gelmiyor!

Are you aware of the danger? No Candy Crush requests for days!

22- Devlet uyan ve isyancılarına gaz sık!

State, wake up and spray pepper to your rebels!

23- Haziran'da Ölmek Zor

It's hard to die in June (Referring to one of the very famous lines of a Turkish poem, Haziranda Olmek Zor by Hasan Huseyin Korkmazgil)

24- Kahvaltımı yaptım artık direnebilirim.

I had my breakfast, now I can rebel.

25- Ne devrim ne şeriat sadece saygi!

No revolution, nor religious law, only respect!

26- Merak etme anne önden yürümüyorum, beraber yürüyoruz! 
Don't worry, mum, I am not at the front, we walk together!

27- Polis Bey, çirkin olduğunzu kadar küstahsınız da!

Mr. Policeman, you are also insolent as much as you are ugly!

28- Welcome to Fight Club Tayyip! (Originally in English - Referring to the famous Hollywood movie 'Fight Club')

29- Freddie Mercury'nin Askerleriyiz!

We are soldiers of Freddie Mercury! (the popular rock icon)

30- Mustafa Keser' in Askerleriyiz!

We are soldiers of Mustafa Keser! (a famous Turkish singer)

31- Halk gündüz Clark Kent, gece Süpermen!

The people are Clark Kent during the day, and Superman during the nighttime.

32- Üç gündür banyo yapmadık, TOMA'ları gönderin!

We haven't taken a shower for 3 days, so send us RCV's! (Riot Control Vehicles)

33- Sekiz gündür TOMA'larla çıkıyoruz, niyetimiz ciddi.

We have been dating RCVs for 8 days, so we are planning to get married.

34- Durmadan öpüşüyoruz Tayyip!

We are constantly kissing Tayyip!

35- Biber gazı oley!

Pepper spray, ole!

36- Bir porsiyon daha gaz lütfen!

Another serving of gas, please!

37- Biber soslu demokrasi!

Pepper sauce democracy!

38- I am chapulling in Istanbul, with my eyes wide shut (Referring to another famous line of Turkish poetry Istanbul'u Dinliyorum, which means "I am Listening to Istanbul" by Orhan Veli)

39- Benim gibi 3 çocuk ister misin?

Do you want 3 kids like me? (Referring to the PM's speech, who suggested that people should have at least three children)

40- In Taksim we trust! (Originally in English)

41- Rebel so hard, Tayyip wanna gas me! (Originally in English)

42- Slogan bulamadim.

I couldn't think of any slogans.

43- Hepimiz Pokemonuz.

We are all Pokemons. (Referring to the famous cartoon character Pokemon)

44- I am chapulling everyday. (Originally in English) 


\section{References}

Bakhtin, M. (1984). Rabelais and his World. Indiana: Indiana University Press.

Broich, U. (1997). 'Intertextuality', in Bertens, H. \& Fokkema, D. (eds.), International Postmodernism: Theory and Literary Practice, Amsterdam: John Benjamin, pp. 249-257.

Czajka, A. \& Wastnidge, E. (2015). 'The centre of world politics? Neo-ottomanism in Turkish foreign and domestic politics'. Retrieved September 17, 2015 from http://web.isanet.org/Web/Conferences/GSCIS\%20Singapore\%202015/Archive/a1b05e35 -80f6-40ae-9c56-b5708c5c321e.pdf

Emre, P.O.,Coban, B. \& Sener, G. (2013). 'Humorous form of protest: Disproportionate use of intelligence in Gezi Park's resistance'. Paper presented at Politsci' 13 Political Science Conference. Istanbul, Turkey, 31 October- 02 November. Retrieved December 14, 2015 from http://doc.utwente.nl/92922/1/Politsci13baski-libre.pdf

Fairclough, N. (1992). Discourse and Social Change. Cambridge: Polity Press.

Fairclough, N. (1995). Media Discourse. London: Edward Arnold.

Fairclough, N. (2003). 'Critical discourse analysis and change in management discourse and ideology: A transdisciplinary approach to strategic critique'. Paper presented at the Second International Conference on Discourse, Communication and Enterprise, Vigo, Spain, 12-14 November. Retrieved August 20, 2015 from https://www.hitpages.com/doc/4645376229376000/13/

Gole, N. (2013). Gezi: Anatomy of public square movement. Today's Zaman [online]. Retrieved September 10, 2015 from www.todayszaman.com/news-317643-gezi-anatomyof-public-square-movementby-nilufer-gole-.html

Gurevich, A. (1997). 'Bakhtin and his theory of carnival', in Bremmer, J. \& Roodenburg, H. (eds.), A Cultural History of Humour: From Antiquity to the Present Day. Cambridge: Polity Press, pp. 54-60.

Hanauer, D.I. (2004). 'Silence, voice and erasure: psychological embodiment in graffiti at the site of Prime Minister Rabin's assassination'. The Arts in Psychotherapy. 1 (31), pp. 2935 .

Hardt, M. (2014). Innovation and obstacles in Istanbul one year after Gezi. EuroNomade. Retrieved February 29, 2016 from http://www.euronomade.info/?p=2557

Hodges, A. (2011). The War on Terror Narrative: Discourse and Intertextuality in the Construction and Contestation of Sociopolitical Reality. Oxford: Oxford University Press.

Jorgensen, M. and Phillips, L. (2002). Discourse Analyses as Theory and Method. London: Sage.

Keyder, C. (2013). Gezi Park1 protestolari baglaminda yeni orta siniflar, neo-liberal donusum ve yoksulluk. [online] KonuşaKonuşa. Retrieved September 20, 2015 from http://konusakonusa.org/2013/09/05/gezi-parki-protestolari-baglaminda-yeni-orta-siniflarneo-liberal-donusum-ve-yoksulluk/

Kitis, D. (2011). 'The subversive poetics of a marginalized discourse and culture', in Foust, E. \& Fuggle, S. (eds.), Words on the Street, London: Institute of Germanic \& Romance Studies, pp. 53-70.

Kuipers, G. (2008) 'The sociology of humor', in Raskin, V. (ed.), Read First! The Primer of Humor Research, New York: Mouton de Gruyter, pp. 365-402.

Kutz-Flamenbaum, R.V. (2014). 'Humor and social movements'. Sociology Compass 8 (3), pp. 294-304.

Lynch, O.H. (2002). 'Humorous communication: Finding a place for humor in communication research'. Communication Theory (12) 4, pp. 423-445.

Pennycook, A. (2010). Language as a Local Practice. London:Routledge. 
Robinson, A. (2011). 'In theory Bakhtin: Carnival against capital, carnival against power'. [online] Ceasefire. Retrieved October 12, 2015 from https://ceasefiremagazine.co.uk/intheory-bakhtin-2/

Romanos, E. (2012). 'The strategic use of humor in the Spanish Indignados/15M Movement'. Paper presented at the Politics and Protest Workshop CUNY Graduate Center, New York, USA, 4 October. Retrieved December 14, 2015 from http://politicsandprotest.ws.gc.cuny.edu/files/2012/07/PPW-4-Romanos.pdf

Sabral, J. \& Erdim, Z. (2013). 'Will Istanbul's protestors have the last laugh?' [online] BBC News. Retrieved March 21, 2016 from http://www.bbc.com/news/world-europe$\underline{22823730}$

Sorensen, M.J. (2008). 'Humor as a serious strategy of nonviolent resistance to oppression'. Journal of Peace and Change 33 (2), pp. 167-190.

Sahin, B. (2013). 'Farkl1lık hosgoru ve AK Parti iktidari: Gezi Parki surecinin dusundurdukleri'. Liberal Dusunce 18 (71), pp. 161-169.

Vandaele, J. (2002). '(Re)constructing humour: meanings and means'. The Translator 8 (2), pp. 149-172.

Van Dijk, T.A. (1995) 'Ideological discourse analyses'. Retrieved March 24, 2016 from http://discourses.org/OldArticles/Ideological\%20discourse\%20analysis.pdf

Yegenoglu, M. (2013). 'Smells like Gezi sprit'. [online] Radical Philosophy: Philosophical Journal of the Independent Left. Retrieved August 5, 2015 from www.radicalphilosophy.com/commentary/smells-like-gezi-spirit

http://duvardakisesler.com/archive. Available online. [Retrieved August 5, 2015].

http://www.listelist.com/gezi-parki-direnisini-anlatan-83-duvar-yazisi/. [Retrieved August 5, 2015].

http://duvardageziparki.tublr.com.[Retrieved August 5, 2015]. 